

\section{The Analysis of the Relationship between Key Audit Matters (KAM) and Firm Characteristics: The Case of Turkey}

\author{
Elif Güneren Genç \\ Başak Erdem
}

\section{Introduction}

Financial scandals are repeated throughout history and the increased frequency of these scandals in the last couple of decades has brought much attention to the accounting and audit profession. Auditor communications with company stakeholders have attracted considerable interest from regulators and standard setters. There has been a growing criticism toward the traditional pass/fail model for audit reports by regulators (Church, Davis, \& McCracken, 2008; Pinto and Morais, 2019).

The main goals of audit report regulations can be listed as reduction of information asymmetry and rise in audit quality as well as financial reporting. Cordos \& Fulpa (2015) examined the reduction of information asymmetry between auditors and users in their paper by extending the audit reporting information content.

International Auditing and Assurance Standards Board (IAASB) has lauched the "New Auditor Reporting Project" in 2011 to build trust in audit reports and to make the auditor reports more insightful and transparent for different stakeholders of the firms. The review of the International Standards on Auditing about the composition and content of the audit report can be presented as the initiation point. On January 2015, the IAASB discussions about auditor reports resulted in six revised and one new Standard. These revisions have been decided to be implemented for periods ending on or after December 15, 2016. The most important change is made on the new Standard ISA 701 Communicating Key Audit Matters in the Independent Auditor's Report.

Turkey followed the ISA 701 (BDS 701) "Communicating Key Audit Matters in the Independent Auditor's Report" regulations in the field of key audit matters (KAMs) in 2017 by the Public Oversight, Accounting and Auditing Standards Authority. The main purposes of including additional key audit matter sections in audit reports can be listed as the increase in transparency of audit reports and the presentation of the auditor's own perception to stakeholders about most important matters. KAM section conveys auditor's perspective about challenging audit matters to users.

Key audit matters (KAMs) are explained under four headings: i) determining KAMs, ii) communicating KAMs, iii) communication with those charged with governance, iv) documentation. According to ISA/BDS
701, key audit matters section should determine and disclose the most important issues in the audit of financial statements according to auditor's professional judgment. KAMs are not standard texts. The content of KAMs may vary from company to company and for different subject matters.

There are a number standards that regulate whether an audit matter should be considered as a KAM, but there is a limited amount of information about the number of KAMs that needs to be reported. Sirois (2018) states which and how many KAMs should be reported is an issue of professional judgment. Although IAASB (2015, A59) and PCAOB $(2017,37)$ proposed that at least one KAM should be reported, regulators warn that "Lengthy lists of key audit matters may be contrary to the notion of such matters being those of most significance in the audit" (IAASB 2015, A30).

According to Codos \& Fulop (2015), two to seven issues should be reported as KAMs. The decisionmaking process is sophisticated and includes diverse elements, sub-processes and tasks. The KAMs in the audit reports are susceptible to certain influence from auditors and entities being audited. The examination of these factors enables us to determine the quality of audit (Ferreira and Morais, 2019). ISA/BDS 701 states that KAM numbers are affected by the size and complexity of the entity, the nature and conditions of its business, and "The facts and circumstances of the audit engagement" (ISA 701, p. A10; BDS 701, p. A30).

From an auditor's perspective, there is a conflict of interest. This is on one hand, being exposed to litigation and loss of reputation and on the other hand the possible loss of a client. The relation between the auditor and the company being audited plays an important role for the number of KAMs being disclosed (Ferreira and Morais, 2019).

This study aims to contribute to the current literature by determining the matters which should be included as KAMs and the factors affecting KAM disclosure. It also examines the relationship between total number of KAMs and firm level characteristics for the Turkish market. The sample is composed of financial data on 30 Turkish companies listed on Borsa Istanbul (BIST) between the years of 2017-2019. As a first step, the number of KAMs in audit reports are analyzed. The KAM independent variables and other variables that may have an effect were analyzed by considering the independent variable.

The remaining sections of this paper are organized as follows: The next section provides the related literature review about the topic. The third section is the empirical study, which includes data and methodology description and findings. The last section is the conclusion, which summarizes the overall findings and explains the limitations of study for further research.

\section{Literature Review}

The implementation of KAMs in audit reports is a relatively new standard. Although the topic is a recent subject in academic studies, it has been extensively studied for different fields. The relationship between KAM and different topics can be classified by the following topics; (i) investors' decisions and capital 
market reactions (Christensen et al.,2014; Boolaky \& Quick, 2016; Bédard et al., 2018; Gutierrez et al., 2018; Lennox et al.,2019; Sirois et al.,2018; Rapley et al., 2018; Köhler et al.,2020) (ii) auditor liability (Brasel et al., 2016; Gimbar et al., 2016; Vinson et al., 2019; Segal, 2019; Pratoomsuwan \& Yolrabil 2020), (iii) auditor judgment (Asbahr \& Ruhnke, 2019; Ratzinger-Sakel \& Theis, 2019,) and (iv) firm and auditor characteristics (Sierra et al.,2019, Ferreira \& Morais 2019, Pinto \& Morais, 2019). Prior literature supports that firm characteristics are one of the main factors affecting the auditor's judgement with respect to KAM (DeFond \& Zhang, 2014; Wu et al., 2016; Velte, 2018; Sierra et al., 2019).

When the literature about KAMs are analyzed for the Turkish market, it is observed that most of the studies are focused on the results of 2017 audit reports. The findings of these studies report that the KAM types concentrate on revenue, trade receivables, fixed assets, tangible assets and inventories (Ertan \& Kızık, 2019; Ciğer et al., 2019b; Çağıran \& Varıcı, 2019; Akdoğan \& Bülbül, 2019; Gökgöz, 2018; Uzay \& Köylü, 2018; Kavut \& Güngör 2018)

Research by Sarisoy \& Kepçe (2019) differs from other studies by examining the expectation gap among different firm stakeholders and financial statement users. A questionnaire was used as an empirical analysis technique in this study. It has been determined that there are expectations among independent audit interest groups in key audit matters.

Sierra at al., conducted a study for 400 companies included in the FTSE-100 (United Kingdom) for the years 2013-2016 in 2019. In this study, they emphasized that the number of auditors and the number of KAM are determined according to the characteristics of customer, and the number of auditors and the type of KAMs are determined according to the characteristics of the customer while establishing the hypotheses. In the results, it was determined that the characteristics of auditor and the client are explanatory in the number and type of KAMs.

Pinto \& Morais, in their study in 2019 wanted to generalize for European countries by determining the factors affecting the number of KAM. For this purpose, they obtained the AEX25 (Netherlands), FTSE-100 (United Kingdom) and CAC40 (France) indexes in 2016. It has been determined that a positive relationship between the number of KAM and the audit fee of the studies, a negative relationship between the number of KAM and the banks, and the more KAM numbers lead to a more complex and sharper accounting standard.

Ferreira and Morais (2019) applied the OLS analysis using 2016 Audit Reports and Consolidated Financial Statements for 447 Brazilian companies participating in BM \& FBovespa in their study. In their study investigating whether the characteristics of the companies audited affect the volume of KAMs, they determined that there is a positive relationship between these factors. In addition, they found a negative relationship between auditor fee and KAMs, and a positive relationship between firm size and KAMs in BM \& FBovespa companies.

In the view of prior literature on number of key audit matters, their determinants and relationship with firm characteristic, i. e. size, industry included, complexity, financial condition and auditor relationships will be examined.

\section{Empirical Study}

This study aims to contribute to the current literature by determining the matters which should be included as KAMs and the factors affecting KAM disclosure. The relationship between firm level characteristics and total number of KAMs disclosed are examined for the Turkish stock market. Non-financial firms of the BIST 30 index are included in the analyses.

The data were collected through two main sources. The KAM data are obtained from publicly available audit reports released by the companies. The financial data are collected from Thomson Reuters EIKON database and from the audited financial statements provided on each company's website.

The study sample consists of Turkish companies listed in BIST30 index between 2017, the year in which communication of KAMs was first introduced in the audit reports, and 2019. The initial sample started with 30 companies. Due to their distinctive operating and regulatory nature, 6 companies operating in the financial sector are excluded. Furthermore, companies that are not listed in all observation years are not included in the analysis. Therefore, the final sample consists of only 18 companies. The list of these companies is provided in Table 1.

\section{Table 1: List of Companies}

\begin{tabular}{|ccc|}
\hline Arcelik & Koza Madencilik & Turkcell \\
Aselsan & Kardemir (d) & Turk Hava Yolları \\
Bim Mağazalar & Petkim & Tekfen Holding \\
Doğan Holding & Pegasus & Tofas Oto. Fab. \\
Ereğli Demir & Sişe Cam & Turk Telekom \\
Çelik & Tav & Tupraş \\
Koza Altın & Havalimanları & \\
\hline
\end{tabular}

Source: Authors' own compilation

Table 2 provides the definitions and measurement of the variables used in this study. 


\section{Table 2: Variable Definitions}

\begin{tabular}{|c|c|c|c|}
\hline Variable & Index & Symbol & Definition \\
\hline \multirow[t]{6}{*}{$\begin{array}{l}\text { Dependent } \\
\text { Variable }\end{array}$} & Kam & KAM & $\begin{array}{l}\text { Total number of matters mentioned in the KAM section of the } \\
\text { audit report }\end{array}$ \\
\hline & Auditor & AUD & $\begin{array}{l}\text { Categorical variable to identify the audit firms: PwC, Deloitte, } \\
\text { Ernst \& Young, KPMG and others }\end{array}$ \\
\hline & Industry & IND & Categorical variable to classify companies by sector \\
\hline & Revenues & LREV & Natural logarithm of revenues \\
\hline & Size & LSIZE & Natural logarithm of total assets \\
\hline & $\begin{array}{l}\text { Return on } \\
\text { Average } \\
\text { Assets }\end{array}$ & ROAA & Profit before taxes divided by average total assets \\
\hline \multirow{6}{*}{$\begin{array}{l}\text { Independent } \\
\text { Variable }\end{array}$} & Leverage & LEV & Total debts divided by total assets \\
\hline & $\begin{array}{l}\text { Current } \\
\text { Ratio }\end{array}$ & $\mathrm{CR}$ & Total current assets divided by total current liabilities \\
\hline & Loss & LS & $\begin{array}{l}\text { Dummy variable that takes zero if the company made a profit in } \\
\text { the previous year and } 1 \text { if the company made a loss }\end{array}$ \\
\hline & Inventories & LINT & Natural logarithm of Inventories \\
\hline & PPE & LPPE & Natural logarithm of Property Plant and Equipment \\
\hline & Switch & SWI & $\begin{array}{l}\text { Dummy variable that takes the value of } 1 \text { if the firm has changed } \\
\text { its auditor since the previous year and zero othervise }\end{array}$ \\
\hline
\end{tabular}

Source: Authors' own compilation

The dependent variable KAM is the total number of matters mentioned in the KAM section of the audit report. To investigate the influence of firm characteristics on KAM number; Auditor, Industry, Revenues, Size, ROAA, Leverage, Current Ratio, Loss, Inventories, PPE and Switch are used as independent variables. In order to avoid problems of scale; Revenues, Size, Inventories and PPE variables are measured as the natural logarithm of the corresponding financial statement caption.

The classification of the companies by industry and KAM disclosure numbers are presented in Table 3 . Thomson Reuters` industry classification methodology is used.

Table 3: Industry Classification of Companies

\begin{tabular}{lccc}
\hline Industries & $\begin{array}{c}\text { Number of } \\
\text { companies }\end{array}$ & $\begin{array}{c}\text { KAM } \\
\text { disclosure } \\
\text { number }\end{array}$ & $\begin{array}{c}\text { Mean number } \\
\text { of KAM } \\
\text { disclosures }\end{array}$ \\
\hline Aerospace \& Defense & 1 & 7 & 3,33 \\
Automobiles \& Auto Parts & 1 & 10 & 2,33 \\
Chemicals & 1 & 3 & 1 \\
Construction \& Engineering & 1 & 6 & 2 \\
Diversified Retail & 1 & 5 & 1,67 \\
Oil \& Gas & 1 & 5 & 1,67 \\
Household Goods & 1 & 10 & 3,33 \\
Industrial Conglomerates & 2 & 7 & 3,5 \\
Telecommunications Services & 2 & 29 & 4,83 \\
Passenger Transportation Services and & 3 & 24 & 2,67 \\
Transport Infrastructure & 4 & 29 & 2,41 \\
Metals \& Mining & & &
\end{tabular}

Source: Authors' own compilation

The most represented industries in the final sample are Metals and Mining with 4 companies as well as Passenger Transportation Services and Transport Infrastructure industry with 3 companies. When the mean number of KAM disclosures are examined, Chemicals industry shows the lowest mean KAM disclosure value of 1 and Telecommunication Services presents the highest mean KAM disclosures with a value of 4,83 .

Table 3 shows statistical description of each variable including mean, median, minimum, maximum and standard deviation. Since Auditor (AUD) is a categorical variable and Switch (SWI) and Industry (IND) are dummy variables, they are not included in Table 4.

\section{Table 4: Descriptive Statistics}

\begin{tabular}{|c|c|c|c|c|c|c|c|c|c|c|c|c|c|}
\hline & \multicolumn{5}{|c|}{2017} & \multicolumn{4}{|c|}{2018} & \multicolumn{4}{|c|}{2019} \\
\hline & Obs. & Mean & Std. Dev. & Min & Max & Mean & Std. Dev. & Min & Max & Mean & Std. Dev. & Min & Max \\
\hline KAM & 18 & 3,050 & 1,210 & 1,000 & 6,000 & 2,722 & 1,274 & 1,000 & 6,000 & 2,388 & 1,036 & 1,000 & 5,000 \\
\hline LREV & 18 & 9,143 & 1,097 & 6,874 & 10,895 & 9,466 & 1,079 & 7,384 & 11,391 & 9,667 & 0,969 & 7,954 & 11,40 \\
\hline LSIZE & 18 & 9,514 & 0,829 & 8,047 & 11,136 & 9,798 & 0,836 & 8,374 & 11,599 & 10,017 & 0,825 & 8,755 & 11,89 \\
\hline ROAA & 18 & 0,092 & 0,060 & $-0,025$ & 0,198 & 0,124 & 0,099 & $-0,040$ & 0,340 & 0,933 & 0,090 & 0,010 & 0,330 \\
\hline LEV & 18 & 0,277 & 0,179 & 0,000 & 0,563 & 0,290 & 0,203 & 0,000 & 0,580 & 0,301 & 0,185 & 0,000 & 0,580 \\
\hline$C R$ & 18 & 2,303 & 2,654 & 0,850 & 9,790 & 2,900 & 4,010 & 0,810 & 14,910 & 2,676 & 3,561 & 0,800 & 12,78 \\
\hline IS & 18 & 0,055 & 0,235 & 0,000 & 1,000 & 0,055 & 0,235 & 0,000 & 1,000 & 0,000 & 0,000 & 0,000 & 0,000 \\
\hline LINT & 18 & 5,427 & 2,380 & 2,579 & 9,040 & 5,711 & 2,312 & 2,796 & 9,247 & 5,833 & 2,280 & 2,738 & 6,355 \\
\hline LPPE & 18 & 8,155 & 1,212 & 6,146 & 10,800 & 8,397 & 1,272 & 6,511 & 11,201 & 8,588 & 1,395 & 9,352 & 11,53 \\
\hline
\end{tabular}

Source: Authors' own compilation

Table 4 shows that, the mean KAM disclosure number for 2017 is 3,05 and decreases to 2,722 in 2018 and 2,388 in 2019. The mean KAM disclosure is decreasing throughout the years. The highest number of mean KAM disclosure is observed in 2017 , which is the beginning year for KAM disclosure regulation. The standard deviation of KAM is 1,210, 1,274 and 1,036 respectively, implying a decreasing variation existing across firms through the recent years. The distribution ranges from 1 to 6 for 2017 and 2018, and 1 to 5 for 2019. With regard to the financial variables, the firms in the sample have an average ROAA of 0,092 for 2017, 0,124 for 2018 and 0,933 for 2019 . The mean LEV is increasing slightly throughout the observation period from $0,277,0,290$ and 0,301 .

Table 5: The Results of Regression Model

\begin{tabular}{|c|c|c|c|c|c|c|c|c|c|}
\hline $\begin{array}{l}\text { Independent } \\
\text { Variables }\end{array}$ & \multicolumn{3}{|c|}{2017} & \multicolumn{3}{|c|}{2018} & \multicolumn{3}{|c|}{2019} \\
\hline c & 12,12 & (3,93) & **** & 8,39 & $(2,95)$ & *** & 1,24 & $(2,57)$ & \\
\hline LSIZE & $-2,40$ & $(0,83)$ & $* *$ & $-1,67$ & $(0,57)$ & $* *$ & $-1,05$ & $(0,45)$ & $* *$ \\
\hline LINT & 0,71 & $(0,16)$ & $* * *$ & 0,65 & $(0,11)$ & $* * *$ & 0,53 & $(0,09)$ & $* * *$ \\
\hline LPPE & 1,18 & $(0,47)$ & $* *$ & 0,72 & $(0,32)$ & $* *$ & 0,91 & $(0,26)$ & $*$ \\
\hline SWI & 0,96 & $(0,49)$ & $*$ & & & & & & \\
\hline IND & & & & 0,10 & $(0,04)$ & $* *$ & & & \\
\hline $\mathrm{ROAA}$ & & & & & & & 8,24 & $(2,31)$ & $* * *$ \\
\hline $\bar{F}$ & & 4,72 & "*** & & 12,48 & "**** & & 9,68 & "***** \\
\hline $\mathrm{R}^{2}$ & & 0,59 & & & 0,79 & & & 0,74 & \\
\hline
\end{tabular}

Source: Authors' own compilation

Notes: Figures next to the estimated coefficients in parenthesis are standard errors.

$* * *, * * *$ indicates significance at $1 \%, 5 \%$ and $10 \%$ statistical levels respectively. 
Table 5 presents model results for 2017, 2018 and 2019. The independent variables that were found significant are respectively: LSIZE, LINT, LPPE, SWI, IND and ROAA. The insignificant variables of Auditor, Revenue, Leverage, Current Ratio and Loss are removed from the model. Company size has a negative and significant effect on KAM number for all three years. The inventory level of firms has a positive and significant effect on KAM number. Property plant and equipment is positively related to KAM. The coefficients for LSIZE and LINT are lower in more recent years. The effect of Auditor Switch shows a positive relation with KAM only in 2017 and similarly Industry is positively related to KAM only in 2018. ROAA presents a significant positive relationship only in 2019.

\section{Conclusion}

The paper explains the relationship between firm characteristics and KAM matters by using an empirical model between the years of 2017 and 2019. The findings in our model show a negative relationship between company size and KAM matters disclosed in audit reports. Our findings are in line with the previous literature and confirm that large firms have more power to negotiate with auditors in terms of audit fees and they can put more pressure on the auditors to disclose less KAM. 2017 is the year in which communication of KAMs was first introduced. When we analyze the data, we can observe that number of disclosed KAM matters for large firms show a decreasing trend throughout the years.

Inventory is one of the challenging areas to audit, therefore have a higher probability of error and requires specialized audit procedures. The previous literature supports that firms with extensive inventory increase the inherent risk (Simunic, 1980; Stice, 1991). Firms with a large amount of inventory stock are considered as complex situations in terms of KAM matters by auditors. This causes an increase in the inherent risk and number of KAM disclosure matters. An adverse effect on number of KAM disclosure can be observed since the inventory related matters are considered by firms and as a result are not disclosed by auditors as KAM. This argument is supported by our results, which show a decreasing number of KAM disclosures throughout the years.

Plant, property and equipment (PPE) investments are very common in Telecommunication, Industrial Conglomerates and Household Goods industries. The high amount of PPE figures causes an increased amount of KAM disclosure matters. Our results confirm this positive significant relation between PPE and KAM.

The profitability is reflected by ROA in our analysis and shows how much profit a company is able to generate from its assets. The results show significant positive relationship between profitability and KAM disclosure for 2019.

Auditor switch shows a positive significant effect on KAM disclosure result only for 2017. The majority of BIST30 companies are audited by Big4 audit firms. We can conclude that, the change among Big4 audit firms does not present a significant effect on the number of KAM disclosures. This shows a unified audit judgment among Big4 audit firms. However, we believe that the effectiveness and integrity of Big4 audit firms should be analyzed separately in future studies to prevent systemic problems in audit matters.

In future studies some limitations of this study can be extended by: 1) including all the companies in Borsa Istanbul (BIST) and 2) analyzing topic-wise classification of KAM disclosure matters. The KAM disclosure requirement started on 2017 in Turkey. In the following years, it would be possible to improve the study as the number of observation period increases.

\section{References}

Akdoğan, N., \& Bülbül, S. (2019). The evaluation of the initial results with respect to the key audit matters stated in the independent auditors' reports issued for the companies listed in Bist 100 Index. Accounting \& Auditing Review, 18(56), 1-24.

Annette Köhler, Nicole Ratzinger-Sakel \& Jochen Theis (2020). The effects of key audit matters on the auditor's report's communicative value: experimental evidence from investment professionals and non-professional investors, Accounting in Europe, 17(2), 105-128.

Asbahr, K., \& Ruhnke, K. (2019). Real effects of reporting key audit matters on auditors' judgment and choice of action. International Journal of Auditing, 23(2), 165-180.

Boolaky, P. K., \& Quick, R. (2016). Bank directors' perceptions of expanded auditor's reports. International Journal of Auditing, 20(2), 158174.

Brasel, K., Doxey, M., Grenier, J. H., \& Reffett, A. (2016). Risk disclosure preceding negative outcomes: The effects of reporting critical audit matters on judgment of auditor liability. The Accounting Review, 91(5), 1345-1362.

Christensen, B. E., Glover, S. M., \& Wolfe, C. J. (2014). Do critical audit matter paragraphs in the audit report change nonprofessional investors, Auditing A Journal of Practice \& Theory, 33 (4), 71-93.

Church, B., Davis, S., \& McCracken, S. (2008). The auditor's reporting model: A literature overview and research synthesis. Accounting Horizons, 22(1), 69-90.

Çiğer, A., Vardar, G. C., \& Kınay, B. (2019a). Key audit matters: A research on listed firms in CEE countries and Turkey. Business and Economic Horizons (BEH), 15(1232-2020-354), 393-422.

Çiğer, U. A., Vardar, G. C., \& Kinay, B. (2019b). The analysis of key audit matters in independent auditors' reports: the case of borsa Istanbul. Mali Cozum Dergisi/Financial Analysis, 29 (153), 109-148. 
Cordos, G.-S. and Fulop, M.-T. (2015), Understanding audit reporting changes: introduction of key audit matters, Journal of Accounting and Management Information Systems, 14, 128152.

DeFond, M., \& Zhang, J. (2014). A review of archival auditing research. Journal of Accounting and Economics, 58(2-3), 275-326.

Ertan, Y., \& Kizık, E. (2019). Key audit matters: investigation of BIST manufacturing companies 2017 audit reports. Journal of Accounting \& Finance, Special Issues, 263268.

Ferreira, C., \& Morais, A. I. (2019). Analysis of the relationship between company characteristics and key audit matters disclosed. Revista Contabilidade \& Financas, 31(83), 262-274.

Gimbar, C., Hansen, B., \& Ozlanski, M. E. (2016). The effect of critical audit matter paragraphs and accounting standard precision on auditor liability. The Accouting Review, 91(6), 16291646.

Gold, A., Heilmann, M., Pott, C., \& Rematzki, J. (2020). Do key audit matters impact financial reporting behavior? International Journal of Auditing, 24 (2), 232-244.

Gökgöz, A. (2018). Reporting key audit matters within the independent audit's report and a study on the companies listed in Istanbul Stock Exchange. Journal of Accounting, Finance and Auditing Studies, 4 (2), 92-105.

Gutierrez, E., Minutti-Meza, M., Tatum, K. W., \& Vulcheva, M. (2018). Consequences of adopting an expanded auditor's report in the United Kingdom. Review of Accounting Studies, 23(4), 1543-1587.

Kalıpcı Çağıran, F., \& Varıcı, I. (2019). Key audit matters within the framework of isa 701: an analysis on audit reports of companies listed in bist manufacturing industry. International Journal of Economic and Administrative Studies, 22, 193-208.

Kavut, F. L. \& Güngör, N. (2018). Key audit matters in independent audit: An analysis on firm listed in The Bist-100 in 2017. Journal of Accounting Institute. 16 (59), 59-70.

Kim, Kwang Yoon, Han Soo Kim, and Sung Jin Park. (2016). The effect of implementation of the new and revised international auditor's reporting standards on Korea's audit environment. Accounting Information Review, 34, 509-31.
Lennox, C. S., Schmidt, J. J., \& Thompson, A. (2019). Are expanded audit reports informative to investors? Evidence from the U.K, SSRN Electronic Journal. Working paper.

Pinto, I, \& Morais A.I. (2019). What matters in disclosures of key audit matters: Evidence from Europe. Journal of International Financial Management \& Accounting, 30, 145-62.

Pratoomsuwan, T., \& Yolrabil, O. (2020). Key audit matter and auditor liability: evidence from auditor evaluators in Thailand. Journal of Applied Accounting Research, 21(4), 741-762.

Rapley, E. T., Robertson, J. C., \& Smith, J. L. (2018). The Effects of Disclosing Critical Audit Matters and Auditor Tenure on Investors' Judgments. Available at SSRN 3294340.

Ratzinger-Sakel, N. V. S., \& Thei, J. C. (2019). Does considering key audit matters affect auditor judgment performance? Corporate Ownership \& Control, 17(Special Issue), 196-210.

Sarısoy, O., \& Kepçe, N. (2019). Communicating key audit matters in the independent auditor's report and expectation GAP, Mali Cozum Dergisi/Financial Analysis, 29 (153), 39-66.

Segal, M. (2019). Key audit matters: insight from audit experts. Meditari Accountancy Research. 27(3), 474-494.

Sierra-García, L., Gambetta, N., García-Benau, M. A., \& Orta-Pérez, M. (2019). Understanding the determinants of the magnitude of entity-level risk and account-level risk key audit matters: The case of the United Kingdom. The British Accounting Review, 51(3), 227-240.

Sirois, L.-P., Bédard, J., \& Bera, P. (2018). The Informational value of key audit matters in the auditor's report: evidence from an eye-tracking study. Accounting Horizons, 32(2), 141-162.

Uzay, S. \& Koylu, C. (2018). Key audit matters: a research on borsa Istanbul. Erciyes University Journal of Faculty of Economics and Administrative Sciences, 52, 47-70.

Velte, P. (2018). Does gender diversity in the audit committee influence key audit matters' readability in the audit report? UK evidence. Corporate Social Responsibility and Environmental Management, 25(5), 748-755.

Vinson, J. M., Robertson, J. C., \& Cockrell, R. C. (2019). The effects of critical audit matter removal and duration on jurors' assessments of auditor negligence. Auditing: A Journal of Practice \& Theory, 38(3), 183-202. 
Wu, C. Y. H., Hsu, H. H., \& Haslam, J. (2016). Audit committees, non-audit services, and auditor reporting decisions prior to failure. The British Accounting Review, 48(2), 240-256. 